\title{
The Contribution of Listening Strategy Instruction to Improving Second Language Listening Comprehension: A Case of Iranian EFL Learners
}

\section{Jalil Fathi}

Asst. Prof., TEFL, University of Kurdistan, Iran, jfathi13@yahoo.com

Razieh Hamidizadeh

MA in TEFL, Islamic Azad University, Malayer Branch, Iran

As an attempt to shed more light on the effectiveness of strategy instruction in second language (L2) learning, the present study was set to investigate the contribution of listening strategy instruction to improve listening comprehension of English as foreign language (EFL) learners in Iranian context. In so doing, a number of 52 English literature students of two intact classes at Islamic Azad University, North Tehran Branch, in Iran served as the participants of the study. The two classes were randomly assigned to an experimental group and a control group. The experimental group received the listening strategy instruction according to the approach proposed by Yeldham and Gruba (2014), whereas the control group was taught with regular method with no strategy instruction. The listening section of the International English Language Testing System (IELTS) was administered to measure the listening comprehension ability of the students before (i.e., as pre-test) and after (i.e., as post-test) the strategy instruction. Oxford Placement Test (OPT) was also administered to ensure the homogeneity of the participants with regard to their general English proficiency. The findings revealed that the experimental group significantly outperformed the control group on the listening performance test, suggesting that the listening strategy instruction was effective in enhancing listening comprehension of the participants.

Keywords: listening strategy instruction, listening comprehension, EFL, strategy-based instruction, language learners

\section{INTRODUCTION}

Although listening plays a key role in communication and has historically proved to be a challenging skill, it has not received adequate attention in second language (L2) research (Lynch, 2011). Once considered as an ability which would develop of its own accord naturally, listening is currently conceptualized as the skill whose development calls for more formal teaching and instruction (Goh, 2010). Subscribing to this view of listening,

Citation: Fathi, J., \& Hamidizadeh, R. (2019). The Contribution of Listening Strategy Instruction to Improving Second Language Listening Comprehension: A Case of Iranian EFL Learners. International Journal of Instruction, 12(2), 17-32. https://doi.org/10.29333/iji.2019.1222a 
scholars and researchers have employed listening strategy instruction as an effective approach for teaching this skill (Graham, 2017). As a result, in order to make improvements in the listening performance of L2 learners, numerous strategy instruction studies have been carried out (e.g., Graham \& Macaro, 2008; Vandergrift \& Tafaghodtari, 2010). The significance of strategy instruction is pointed out by Brown (2007), who maintains, "Because by definition interaction is unrehearsed, mostly unplanned discourse, students need to have the necessary strategic competence to hold their own in the give and take of meaningful communication" (pp. 258-259).

In spite of its widespread use, the notion of language learning strategies has been defined differently by various scholars and has been the subject of some debate among numerous scholars in the field (Dörnyei, 2005; Oxford, 2011). Oxford (2011) views language learning strategies as a set of intentional, systematic, and purposeful activities employed to monitor and direct attempts in order to learn the second language. Among the various proposed definitions, one point of agreement among researchers lies in their conceptualization of language learning strategies as goal-directed and metacognitive constructs, involving learner responsibility and some degree of consciousness to attend to learning tasks (Cohen \& Macaro, 2007). Within the accumulated body of literature dealing with language learning strategies, the vast majority of the studies have been more concerned with strategy use than with strategy instruction (Gunning \& Oxford, 2014). The growing body of research into language learning strategies state that strategy instruction encourages language learners to foster the competent application of strategies (Chamot, 2005b), and that there is an overall positive relationship between the successful use of strategies and successful use of second language (Oxford et al., 2004).

Effective listening comprehension is conceptualized as the cooperation of top-down and bottom-up processes in a balanced fashion (Vandergrift, 2004). Strategy use will help learners to orchestrate these processes in a productive manner. Strategies constitute direct and conscious procedures designed to enhance L2 listening and to compensate for actual or anticipated comprehension breakdowns (Field, 2008). Concerning the types of listening strategies, Vandergrift (1997) provides a comprehensive taxonomy of the listening strategies and their definitions, categorized based on O'Malley and Chamot's model (1990) of metacognitive, cognitive, and socioaffective strategies. Cognitive strategies help learners to manipulate the input to foster understanding, metacognitive strategies contribute to the listeners' orchestration of their strategy use, and help them manage their listening performance more effectively by planning, monitoring, and evaluating their listening (Vandergrift, 2003).

Encouraging listening strategy use through explicit instruction is argued to be beneficial to promoting learners' effective and autonomous listening (Flowerdew \& Miller, 2005; Vandergrift, 2004). Given the purported benefits of strategies in enhancing L2 listening by numerous researchers (e.g., Goh, 2000; Graham, 2006; Vandergrift \& Tafaghodtari, 2010), intervention studies for listening strategy instruction have been the focus of significant attention in L2 research. The underlying assumption of listening strategy instruction is that L2 language learners can be instructed to model the productive language learning behaviors of the successful language learners. From this perspective, 
listeners are provided with explicit instructional activities such as directing conscious attention to strategies already employed; presenting and modelling strategies; giving adequate opportunities for practice; and evaluating successful transfer of strategies to new language learning tasks and activities (Cohen, 2011). Listening strategy instruction is predominantly concerned with a course of instruction emphasizing a repertoire of strategies considered to be appropriate to accomplishing 'real world' listening tasks (Mendelsohn, 1994). Strategy instruction also assists learners in developing top-down processes to infer meaning from the context and to make more informed guessing according to other available information (Vandergrift, 2007). Although strategy instruction programs are largely concerned with top-down processes, bottom-up listening processes should not be neglected as not only does bottom-up processes foster meaning-based comprehension but they are also highly affected by and dependent on both types of listening processing (Tsui \& Fullilove, 1998).

Overall, more recent strategy instruction studies have adopted either approaches combining explicit strategy instruction and a metacognitive element (e.g., Graham \& Macaro 2008) or more implicit approaches, which are mainly concerned with the development of metacognitive strategies (e.g., Vandergrift \& Tafaghodtari, 2010). The main assumption behind both explicit and implicit approaches is the fact that mere input and exposure to language by itself is insufficient to improve learners' listening. Strategy instruction studies have offered mixed results, with some being effective (e.g., Lee, 2007; Sasaki, 2004; Vandergrift, 2002), some partially effective (O’Malley \& Chamot, 1990), and some others less effective (Rees-Miller,1993; Rossiter, 2003). The less effective results of strategy instruction studies have been attributed to inadequate time devoted to practicing strategies by some scholars (Chamot, 2005a, 2005b).

The relevant literature emphasizes the effective use of strategies in order to yield more successful results. According to Manchón (2008),

[o]ne option is to conceptualize effective use of strategies in terms of whether or not learners are able to orchestrate their strategy deployment in such a way that their self-imposed or other imposed language learning use/goals are achieved, thereby engaging in problem-solving rather than problem-avoiding behavior. (p. 239)

From this perspective, the employment of different models of strategy instruction may lead to different results as each model may offer various combination and orchestration of strategy deployment. Therefore, one reason for the conduction of the present study is to investigate the effectiveness of using the strategy instruction model proposed by Yeldham and Gruba (2014) for listening strategy instruction in Iranian EFL context.

Another reason which warrants conduction of the present study is the potential effect of cultural context on the results of strategy instruction. Strategy instruction should be culturally adapted (Oxford, 2011) and meet the cultural needs of learners in particular contexts (Lee, 2007). Consequently, the unique cultural context of Iran may call for particular types of strategy instruction. Moreover, it seems that in Iranian EFL context, listening is not taught very systematically and this skill is usually neglected and considered to naturally develop after receiving input and being exposed to language data. According to Rahimirad and Shams (2014), "it seems that teaching this skill is 
totally ignored at the school level in Iran and it is not emphasized at the college level either" (p. 166). Listening skill has been given very little attention in the curriculum of schools in public sectors. Nor does it receive adequate weight in scoring system of Iranian foreign language educational system. As far as English majors in universities are concerned, Iranian universities devote some basic courses to improve speaking and listening skills of college students of English majors. However, students don't normally receive strategy instruction for listening skill and they are mostly involved in transcribing audio files, providing the summary of oral texts, and answering to some ready-made multiple choice items as the most frequent exercises practiced in such courses. In other words, English major students are not taught or become aware of workable listening strategies during their usual educational programs offered by English departments. Furthermore, the instructors themselves may not be able to teach listening strategies. Neither may they be equipped with sufficient and thorough knowledge of listening strategy instruction and their main pedagogic approaches.

This scant attention directed to teaching listening is not new and it is argued that many teachers across various contexts are mainly engaged in doing listening activities or merely testing the learners rather than teaching learners how to listen (Graham, 2017). Finally, given the importance of listening comprehension in L2 learning, replicating research, particularly studies on successful practices in listening pedagogy in EFL contexts would be warranted. Therefore, in order to shed more light on the effectiveness of strategy instruction in L2 learning in general and L2 listening in particular, the present study was set to investigate the contribution of listening strategy instruction to improving listening comprehension of EFL learners in the Iranian context.

\section{REVIEW OF LITERATURE}

In spite of the ever-increasing pedagogical and theoretical supports for L2 listening strategy instruction, there has been little relevant empirical research evidence, and the few studies thus far have not yielded consistent findings to convincingly confirm or disconfirm the effectiveness of listening strategy instruction. For example, conducting a classroom-based, longitudinal study, Thompson and Rubin (1996) explored the effect of learner strategy instruction on listening comprehension. The participants of the study were learners enrolled in a Russian language course at a university. The materials employed in the study included video segments from authentic materials developed for Russian learners, segments from Russian television, and movies. The findings revealed that listening strategy instruction improved listening comprehension of the participants. The main limitation of this study was the small sample size. Therefore, the researchers pointed out that further research in other languages with larger samples should be carried out to validate these results.

In another study, Graham and Macaro (2008) carried out a study to investigate the contribution of strategy instruction to enhance the listening comprehension and sense of efficacy of a group of French learners in England. Additionally, the comparative effects of different treatments with various amount of scaffolding were investigated. The findings revealed that the listening strategy instruction enhanced listening proficiency and learners' confidence about listening. In the same vein, Vandergrift and Tafaghodtari 
(2010) indicated the benefits of a metacognitive strategy instruction program, in which strategy training was incorporated into the traditional language instruction programs. The findings of the study revealed that second language learners gained the competencies to choose and coordinate various strategies for their various needs. The metacognitive awareness of the participants was also enhanced. Also, Thompson and Rubin (1996) indicated that an integrated approach enhanced not only the participants' listening comprehension ability but also their motivation and interest in dealing with their more difficult listening assignments outside the classroom.

Cross (2009) conducted a quasi-experimental study to investigate the effect of listening strategy instruction on L2 listening comprehension. The participants of the study were advanced-level, adult, Japanese, EFL learners. The experimental group received a 12 hour listening strategy instruction which included the presentation, practice, and review of listening strategies, whereas the control group was taught regularly and did not receive any explicit strategy instruction. Results demonstrated that the experimental group outperformed the control group significantly. Also, Rahimirad and Shams (2014) carried out a study to investigate the effect of activating metacognitive strategies on the listening performance and metacognitive awareness of EFL students. In so doing, they recruited a sample of 50 students of English literature at the state university in Iran as the participants of the study. The students were randomly assigned to the experimental and control groups. The students of the experimental group underwent the metacognitive strategy instruction according to the models proposed by Vandergrift and Tafaghodtari (2010), whereas the control group students were taught traditionally without any strategy instruction. The results of the listening section of IELTS test administered as pre-test and post-test revealed that the experimental group significantly outperformed the control group on the listening test. In addition, it was found that there was a significant enhancement in the students' level of metacognitive awareness after receiving strategy instruction. The findings of the study were also supported by the conducted interviews with the participants.

In another study, Yeldham and Gruba (2014) investigated the idiosyncratic development of L2 learners after receiving listening strategy instruction. The researchers employed a longitudinal multi-case study to examine the development of four lower proficiencylevel Taiwanese university L2 learners of English. The development of the four EFL learners was investigated longitudinally through a variety of quantitative and qualitative techniques. As the treatment procedure, the learners participated in a course which combined direct instruction of strategies with their practice embedded in the class listening texts. The findings revealed that all learners developed a greater competence in their use of top-down and bottom-up strategies, mainly by selectively integrating appropriate strategies from the course into their listening activities. It was also found that the participants developed in a series of person-related and task-related areas, such as confidence, motivation and sense of control over the listening process. Finally, the researchers argued that individual development in a listening strategy-based instruction involves an intricate interplay between numerous cognitive and individual variables, and varies inter-individually. 
In another study conducted by Bozorgian (2014), the effect of metacognitive strategy instruction on the listening comprehension and metacognitive knowledge of a group of male EFL learners in Iran was investigated. For the purpose of the study, the EFL learners were taught based on a guided lesson plan in metacognition including planning, monitoring, and evaluation via a pedagogical cycle approach over a period of eight weeks of treatment. IELTS listening module tests were employed to measure the students' listening performance. Furthermore, a Metacognitive Awareness Listening Questionnaire (MALQ) was also administered to the participants. The findings of the study revealed that metacognitive instruction improved the students' listening ability. Nevertheless, it was found that the participants did not use metacognitive awareness significantly. Similarly, Maftoon and Alamdari (2016) carried out a study to examine the effect of metacognitive strategy instruction on the listening performance and metacognitive awareness of Iranian EFL learners. Additionally, the study also investigated the effectiveness of metacognitive strategy instruction on learners' metacognitive awareness as measured by five factors of MALQ. The participants included 60 intermediate Iranian EFL learners in two groups. The experimental group $(N=30)$ was taught based on a guided lesson plan in metacognition, whereas the control group $(N=30)$ was instructed regularly and without any guided attention to process. As data collection instruments, the MALQ and a listening test were employed to measure the metacognitive awareness and listening performance. The findings of the study revealed that metacognitive strategy instruction contributed to the development of overall listening performance and metacognitive awareness of participants.

Recently, Bozorgian and Alamdari (2018) carried out a study to examine the effect of metacognitive strategy instruction via dialogic interaction in a collaborative activity on a group of Iranian EFL learners' multimedia listening and their metacognitive awareness in listening comprehension. The participants of the study were three groups of 180 male and female advanced Iranian learners. The two groups serving as the experimental groups were instructed through a structured training program designed for metacognitive instruction via dialogic interaction and metacognitive instruction for a period of 10 sessions. The participants of the experimental group were engaged in 60 minutes of practice twice a week. The third group participants who served as the control group were trained according to regular, traditional method without receiving any metacognitive strategy instruction. To collect the data, multimedia listening tests and the MALQ were administered to measure the learners' listening comprehension and metacognitive awareness. The findings revealed that metacognitive strategy instruction via dialogic interaction enhanced both the learners' multimedia listening comprehension and their metacognitive awareness in listening.

Concerning the above-mentioned studies and other similar studies conducted on strategy instruction, some points should be mentioned. First, such studies did not result in conclusive results and some doubts and concerns can be raised about the effectiveness of strategy instruction in L2 listening (Graham \& Macaro, 2008). For instance, Ridgway (2000) maintained that learners may not possess the cognitive capacity to consciously activate instructed strategies and listen at the same time, and separating individual listening strategies for explicit instruction and identifying whether the 
instructed strategies are being employed by listeners cannot be realistically accomplished. Furthermore, Field (2008) asserted that tendency toward listening strategy instruction and strategy use is contingent upon an individual's temperament. He also maintained that the instruction of individual listening strategies may promote the use of those strategies but may not necessarily result in enhanced listening performance. Additionally, Chen (2005) enumerated a set of barriers which may inhibit the learning of listening strategies during a strategy instruction program. These barriers consisted of affective, strategic, habitudinal, information processing, belief and material, and language proficiency.

\section{PRPOSE OF THE STUDY}

Given the inconclusive results of previous studies and lack of insight from past research into the degree of effectiveness of strategy instruction programs, it is important to investigate the effect of such strategy instruction programs for L2 listening in different contexts. Therefore, as an attempt to shed more light on the effectiveness of strategy instruction in L2learning, the present study was set to investigate the contribution of listening strategy instruction to improving listening comprehension of EFL learners in Iranian context. In so doing, the listening strategy instruction approach proposed by Yeldham and Gruba (2014) was adopted as the model employed for strategy instruction to accomplish the objectives of the present study. The research question guiding this study was:

Does listening strategy instruction significantly improve second language listening comprehension of Iranian EFL learners?

\section{METHOD}

\section{Participants}

A number of 52 English literature students of two intact classes at Islamic Azad University, North Tehran Branch, in Iran served as the participants of the study. The participants in the present study were male and female students aged between 19 and 24. The two classes were randomly assigned to an experimental group $(N=27)$ and a control group $(N=25)$. To ensure the homogeneity of the two groups in terms of English proficiency level "Oxford Placement Test" (Allan, 2004) was administered. As revealed by the results of OPT, the students were classified as upper-intermediate in terms of general English proficiency. All the students had at least 5-year experiences of learning English as a foreign language in English institutes. The two classes were taught by the same teacher who used the same textbook and materials for both classes. The treatment lasted for a period of one university semester which was equal to 16 weeks.

Also, it is worth noting that concerns with regard to sample size might be raised, as a generally recommended minimum sample size for a group in experimental or correlational studies is 30 (e.g., Groom \& Littlemore, 2011). However, since the number of participants in a writing class is usually small, a sample size of 25 may be considered sufficient. Additionally, according to Gay (1992), with carefully designed experimental treatment and control, even a group of 15 students can act as an acceptable sample. 


\section{Instruments}

\section{English Proficiency Test}

Oxford Placement Test (OPT) (Allan, 2004) was administered to determine the homogeneity of the participants with regard to their general English proficiency. OPT is claimed to have the capacity of being administered to any number of English learners to determine their accurate place at all levels (Allan, 2004). OPT has a 6 rating scale; students whose score fall between 0-17 are considered as basic (A1), and students whose scores lie within 18-29 are regarded as elementary students (A2). Those whose scores are between 30 and 39 are in the lower intermediate group (B1).

Those with the scores of 40-47 are considered as upper intermediate (B2) and the students with the scores 48-54, and 54-60 are recognized as advanced (C1) and very sophisticated (C2) levels respectively. The reliability coefficient of OPT as measured by Cronbach's alpha was reported to be 0.86 in the present study.

\section{Listening section of the IELTS}

To measure the listening comprehension ability of the students, the IELTS listening practice tests (Scovell, Pastellas, \& Knobel, 2004) were used as pretest and posttest of the study. There are four parts in the IELTS listening module. The first two parts are concerned with topics of general interest. The first part of the listening tests is in the form of a dialogue, the second is a monologue. The third and the fourth parts are usually related to education or training and often have a lecture and a discussion between two to four people. The listening tests administered in the present study took 30 minutes. The Cronbach's alpha reliability coefficient for the pre- and posttests was .79 and .82 , respectively.

\section{Procedure}

One week before the commencement of the intervention, OPT was given to students to investigate the homogeneity of participants. During the same session, the listening pretest, which was one of the IELTS listening practice tests, was administered to the students of both groups.

In the first session of the treatment for the experimental group, the instructor explained listening strategy instruction to the learners very briefly and provided them with an overview of the procedure of the whole intervention period based on the adopted strategy instruction model in the study. The model used by Yeldham and Gruba (2014) was employed for listening strategy instruction. Yeldham and Gruba (2014) combined a direct approach to strategy instruction previously employed by some researchers (Mendelsohn, 2006; O’Malley \& Chamot, 1990), with Vandergrift's (2007; Vandergrift \& Tafaghodtari, 2010) metacognitive embedded approach. They maintained that this combination was more effective and could compensate for the possible inadequacies in either of the two approaches. Yeldham and Gruba (2014, p. 5) pointed out " a wholly embedded approach runs the risk of becoming monotonous for the learners (Vandergrift \& Tafaghodtari, 2010), while direct practice can be overly prescriptive and may thus fail a variety of learners." 
This listening strategy instruction framework encompasses the three types of top-down, bottom-up, and metacognitive strategies. As for the top-down strategies, the students of the experimental group were instructed to predict and anticipate text content and vocabularies, guess the meaning of difficult words or information in texts, infer unstated aspects of text, use contextual cues to comprehend the text, and use discourse markers to guess difficult content and anticipate the following content. Concerning the bottom-up strategies, the students were taught to use cues and write down key words while listening to facilitate their own comprehension, use discourse markers to guide comprehension, and identify stressed content words in texts. With regard to metacognitive strategies, the participants were trained to gain overview of listening strategies, focus on metacognitive control of strategies, and monitor more effectively, for instance, monitor text for anomalous sentences and monitor texts containing initial misleading schema (Yeldham \& Gruba, 2014).

During the first session of the intervention, the students were provided with an overview of the three categories of strategies discussed above. In succeeding sessions, strategy instruction was integrated into the listening texts, according to a pedagogical cycle by Vandergrift (2007) to help the learners to coordinate their employed strategies. During these sessions, the learners were required to predict the text's content after having listened to its first sentence or to recognize its topic. Consequently, after listening to the text for the first time, they examined their predictions and compared their comprehension with their classmates. While listening for the second time, they again checked their comprehension, and discussed their interpretations of the text with peers. After listening for the third time, they had reflection on their performance and set objectives for future listening tasks. The students in the control group received identical listening tasks and exercises from the same book during the treatment period with no listening strategy instruction.

Finally, one week after the completion of strategy instruction program, the students attended the class and took the post-test of listening which was another practice test of IELTS listening section that was of the same content and difficulty level with pre-test.

\section{Data analysis}

In order to analyze the data collected for the purpose of the present study, the data gathered through the administration of OPT as well as the pre- and the posttest of listening comprehension were analyzed using SPSS version 22. In so doing, both descriptive and inferential statistics were employed. First, to ensure the homogeneity of the groups, an independent-samples t-test was carried out to compare the OPT scores for the experimental and control groups. Then, in order to investigate the effect of the independent variable (listening strategy instruction) on the dependent variable of the study (i.e., learners' listening comprehension), both paired samples $t$-tests and a one-way between-groups analysis of covariance (ANCOVA) were conducted.

\section{FINDINGS}

As discussed above, OPT was administered to ensure the homogeneity of the two groups in terms of general English proficiency prior to the treatment. An independent-samples t-test was conducted to compare the OPT scores for the experimental and control 
groups. As seen in Table 1, the results revealed that there was not a statistically significant difference in the OPT scores for the experimental group $(M=42.66, S D=$ $11.35)$ and the control group $(M=44.50, S D=11.14) ; t(50)=-.587, p>0.05)$, suggesting that the two groups were of the similar level of general English proficiency prior to conduction of the treatment.

Table 1

Results of the OPT for each group

\begin{tabular}{llll}
\hline Groups & M (SD) & $T$ & Sig. \\
\hline Experimental & $42.66(11.35)$ & -.587 & .560 \\
Control & $44.50(11.14)$ & & \\
\hline
\end{tabular}

Then, in order to investigate the effect of the listening strategy instruction on the learners' listening comprehension, paired samples $t$-tests were carried out to compare the listening scores of the listeners in both groups in the pre-test and post-test. The analyses of paired samples t-tests indicated that there was a statistically significant increase of mean scores on the listening comprehension tests for both experimental and control groups. As it can be seen from the results in Table 2, the increase in the listening mean scores of the experimental group was statistically significant $(t=-5.84, p<0.05)$, likewise, the increase in the listening mean scores of the control group was statistically significant $(\mathrm{t}=-2.36, \mathrm{p}<0.05)$. The results demonstrated that the listening mean score of the experimental group was 17.77 on the pre-test and this value increased to 22.93 on the post-test, a change which was statistically significant. Similarly, the listening pre-test mean score for the control group increased from 18.43 to 20.23 on the post-test. This amount of increase was also statistically significant.

Furthermore, a one-way between-groups analysis of covariance (ANCOVA) was conducted to compare the effectiveness of the two types of listening instructions employed in the control group and the experimental groups. The independent variable was the type of treatment condition (i.e. strategy instruction or traditional), and the dependent variable was the scores on the listening test administered after the completion of the treatment. Students' scores on the pre-test of the listening test served as the covariate in this analysis.

Preliminary checks revealed that there was no violation of normality, linearity, homogeneity of variances, homogeneity of regression slopes, and reliable measurement of the covariate. As Table 3 indicates, there was a significant difference between the two groups on post-test scores of listening, $F(1,49)=7.57, p=0.008$, partial eta squared = $0.13)$.

Table 2

Paired samples $t$-test for listening scores in each group

\begin{tabular}{llllllll}
\hline & Pre-test & & & \multicolumn{2}{c}{ Post-test } & & Sig. \\
\cline { 2 - 3 } \cline { 5 - 6 } Groups & $\mathrm{M}$ & $\mathrm{SD}$ & & $\mathrm{M}$ & $\mathrm{SD}$ & $\mathrm{t}$ & $\mathrm{-}$ \\
\hline Experimental & 17.77 & 5.70 & & 22.93 & 6.42 & & 0.00 \\
Control & 18.43 & 5.14 & & 20.23 & 6.47 & -2.36 & 0.02 \\
\hline
\end{tabular}


Table 3

ANCOVA results for listening comprehension scores

\begin{tabular}{lllllll}
\hline Source & $\begin{array}{l}\text { Type III Sum of } \\
\text { Squares }\end{array}$ & df & Mean Square & F & Sig. & $\begin{array}{l}\text { Partial Eta } \\
\text { Squared }\end{array}$ \\
\hline Corrected Model & $293.766^{\mathrm{a}}$ & 2 & 146.883 & 9.115 & .000 & .271 \\
Intercept & 216.441 & 1 & 216.441 & 13.432 & .001 & .215 \\
Pre.Listening & 198.991 & 1 & 198.991 & 12.349 & .001 & .201 \\
Group & 122.007 & 1 & 122.007 & 7.571 & .008 & .134 \\
Error & 789.595 & 49 & 16.114 & & & \\
Total & 25423.168 & 52 & & & & \\
Corrected Total & 1083.361 & 51 & & & & \\
\hline
\end{tabular}

\section{DISCUSSION AND CONCLUSION}

The purpose of the present study was set to investigate the contribution of listening strategy instruction to improve listening comprehension of EFL learners in Iranian context. The strategy instruction model of Yeldham and Gruba (2014) was adopted for the intervention lasting for sixteen weeks. The results from paired samples $t$-tests and a one-way between-groups ANCOVA revealed that the experimental group significantly outperformed the control group on the listening performance test, suggesting that the listening strategy instruction was effective in improving listening comprehension of the participants. The findings of the present study are in line with those of previous similar studies (Cross, 2009; Graham \& Macaro, 2008; Vandergrift \& Tafaghodtari, 2010; Yeldham \& Gruba, 2014, among others) and are at variance with the findings of ReesMiller (1993) and Rossiter (2003). The findings of this study also confirmed those of other similar studies conducted in the Iranian EFL context (e.g., Bozorgian, 2014; Bozorgian \& Alamdari, 2018; Maftoon \& Alamdari, 2016; Rahimirad \& Shams; 2014).

Furthermore, the findings of the present study verified the effectiveness of employing the model proposed by Yeldham and Gruba (2014), which was a combination of the explicit and embedded approaches. This is in line with the suggestion made by numerous scholars that strategy instruction yields the most successful results when it is both explicit and integrated into the L2 language curriculum (Cohen, 2011; O'Malley \& Chamot, 1990; Oxford, 2011). Few intervention studies carried out previously have mainly focused on the explicit teaching of one or more strategies in isolation or along with strategies for other language skills. Yeldham and Gruba's (2014) study was conducted with four Taiwanese EFL learners with low English proficiency level. However, the present study was replicated with a bigger sample of Iranian EFL students of upper-intermediate proficiency level and also employed a quasi-experimental design.

Unlike the majority of previous studies in which the overriding focus was on deployment of metacognitive strategies and top-down processing (e.g., Goh, 1998; O'Malley et al., 1989; Vandergrift, 1997), the present study also employed bottom-up skills and strategies to teach listening. This finding may re-echo that of Yeldham and Gruba (2014), suggesting that employing only bottom-up instruction, without the integration of top-down skills and strategies, is less likely to develop the learners' listening competencies. The method of listening strategy instruction employed in the 
present study involved presenting and modeling strategies and provided students with adequate practice opportunities, which ultimately resulted in the better listening performance of the participants. In fact, the adopted model of the present study is in line with the description of effective strategy instruction methods discussed by some scholars (e.g., Oxford, 1990, 2011).

Iranian students do not appear to be adequately trained in the listening strategies in the EFL context and as stated by Rasekh and Ranjbary (2003), many course books and curricula, especially in the context of EFL, do not address learning strategies effectively. In fact, teaching listening might be alien to many Iranian EFL teachers. In typical listening classrooms in Iran, learners just listen to a text and complete succeeding exercises, which are then corrected. Therefore, the need to employing strategy instruction approach for teaching L2 listening might be a necessity in Iranian context. In the same vein, many L2 listening scholars have pointed out that listening should be instructed in a more theoretically-informed manner in the classroom (e.g., Mendelsohn, 1998; Vandergrift, 2004).

In order to increase the likelihood of the success for strategy instruction and to encourage the learners to learn how to orchestrate their strategy use, practitioners should make attempt to foster positive perceptions of strategies among learners. Learners' negative perception towards strategy use has been reported to be a significant variable in yielding less successful results for strategy instruction studies (Griffiths, 2013; Gunning \& Oxford, 2014). Moreover, listeners should gain more knowledge about the nature of strategies and reflect on a particular strategy which is going to be an important issue which helps listeners become more proficient in their use of strategies (Vandergrift \& Goh, 2012).

In addition, it is recommended that teacher education programs and teacher educators provide the teachers with the necessary skills and knowledge to teach listening. Lack of adequate pedagogical knowledge is mentioned as a contributing factor for teachers' reluctance to teach listening (Siegel, 2014). Moreover, most teachers lack the expertise to prepare their own listening materials and usually use commercially produced materials. As a result, textbook designers and material developers should also provide the language teachers with textbooks and materials which include exercises and tasks supporting strategy instruction.

As far as L2 research is concerned, listening requires further research attention. According to Vandergrift and Cross (2015, p.10), "the covert nature of the cognitive processes and ephemeral nature of the input make listening research more difficult and less attractive than research into the other language skills." This complex and covert nature of listening calls for further studies across different contexts with different learners of various proficiency levels. Within the past literature of L2 research, listening has enjoyed less research attention than the other three language skills (Macaro, Graham, \& Vanderplank, 2007; Vandergrift \& Goh, 2011). This lack of research attention is partially due to the traditional conceptualization of listening in which listening has been viewed as a passive language skill that cannot be taught in class but rather developed naturally and automatically (Rost, 2011; Vandergrift \& Goh, 2012). 
However, listening is currently redefined as "an active process in which listeners select and interpret information which comes from auditory and visual clues" (Rubin, 1995, p. 7).

It is also suggested that future studies be carried out using mixed methods design in order to have a more comprehensive understanding of how different forms of strategies instruction can bring about significant gains in listening comprehension. In addition, further studies should employ longitudinal designs in order to explore long-term benefits of strategy instruction.

\section{REFERENCES}

Allan, D. (2004). Oxford Placement Test. Oxford: Oxford University Press.

Bozorgian, H. (2014). The role of metacognition in the development of EFL learners' listening skill. International Journal of Listening, 28, 1-13.

Bozorgian, H. \& Alamdari, E. F. (2018). Multimedia listening comprehension: Metacognitive instruction or metacognitive instruction through dialogic interaction. ReCALL, 30(1), 131-152.

Brown, H. D. (2007). Teaching by principles: An interactive approach to language pedagogy (3rd ed.). New York: Addison-Wesley.

Chamot, A. U. (2005a). The cognitive academic learning approach (CALLA): an update. In P. A. Richard-Amato, \& M. A. Snow (Eds.), Academic success for English language learners: Strategies for K-12 mainstream teachers (pp. 87-101). White Plains, NY: Longman.

Chamot, A. U. (2005b). Language learning strategy instruction: current issues and research. Annual Review of Applied Linguistics, 25, 112-130. https://doi.org/10.1017/S0267190505000061

Chen, Y. (2005). A qualitative study on the effect of language learning strategy training. Paper presented at the Conference on English Teaching and Learning, at National Taiwan Normal University, Taiwan.

Cohen, A., \& Macaro, E. (2007). Learner strategies. Oxford: Oxford University Press.

Cohen, A. D. (2011). Strategies in learning and using a second language (2nd ed.). Essex, UK: Longman.

Cross, J. (2009). Effects of listening strategy instruction on news videotext comprehension. Language Teaching Research, 13, 151-176. https://doi.org/10.1177/1362168809103446

D“ornyei, Z. (2005). The psychology of the language learner. Mahwah, NJ: Lawrence Erlbaum Associates. Field, J. (2008). Listening in the language classroom. Cambridge: Cambridge University Press.

Field, J. (2008). Emergent and divergent: A view of second language listening research. System, 36(1), 2-9. 
Flowerdew, J. and Miller, L. (2005). Second language listening: Theory and practice. Cambridge: Cambridge University Press. https://doi.org/10.1017/CBO9780511667244

Gay, L. R. (1992). Educational research competencies for analysis and application. New York: Macmillan.

Goh, C. C. M. (1998). How ESL learners with different listening abilities use comprehension strategies and tactics. Language Teaching Research, 2, 124-147. https://doi.org/10.1177/136216889800200203

Goh, C. (2000). A cognitive perspective on language learners' listening comprehension problems. System, 28, 55-75. https://doi.org/10.1016/S0346-251X(99)00060-3

Goh, C. (2010). Listening as process: Learning activities for self-appraisal and selfregulation. In N. Harwood (ed.), English language teaching materials: Theory and practice. Cambridge: Cambridge University Press, 179-206.

Graham, S. (2006). Listening comprehension: The learners' perspective. System, 34, 165-182. https://doi.org/10.1016/j.system.2005.11.001

Graham, S. (2017). Research into practice: Listening strategies in an instructed classroom setting, Language Teaching, 5O(1), 107-119. https://doi.org/10.1017/S0261444816000306

Graham, S. \& E. Macaro (2008). Strategy instruction in listening for lower-intermediate learners of French. Language Learning, 58 (4), 747-783. https://doi.org/10.1111/j.1467-9922.2008.00478.x

Griffiths, C. (2013). The strategy factor in successful language learning. Bristol: Multilingual Matters. https://doi.org/10.21832/9781847699428

Groom, N., \& Littlemore, J. (2011). Doing applied linguistics: A guide for students. London: Routledge.

Gunning, P., \& Oxford, R.L. (2014). Children's learning strategy use and the effects of strategy instruction on success in learning ESL in Canada. System, 43, 82-100. https://doi.org/10.1016/j.system.2013.12.012

Lee, K. R. (2007). Strategy awareness-raising for success: Reading strategy instruction in the EFL context. $\mathrm{PhD}$ thesis. College Park, Maryland: University of Maryland. http://drum.lib.umd.edu/handle/1903/6859.

Lynch, L. (2011). Academic listening in the 21st century: Reviewing a decade of research. Journal of English for Academic Purposes, 10, 79-88. https://doi.org/10.1016/j.jeap.2011.03.001

Macaro, E., Graham, S., \& Vanderplank, R. (2007). A review of listening strategies: Focus on sources of knowledge and on success. In A.D. Cohen, \& E. Macaro (Eds.), Language learner strategies: 30 years of research and practice (pp. 165-185). Oxford: Oxford University Press.

Manchón, R. (2008). Taking strategies to the foreign language classroom: where are we now in theory and research? International Review of Applied Linguistics and Language Teaching, 46, 221-243. https://doi.org/10.1515/IRAL.2008.010 
Maftoon, P. \& Alamdari, E. F. (2016). Exploring the effect of metacognitive strategy instruction on metacognitive awareness and listening performance through a processbased approach, International Journal of Listening. doi: 10.1080/10904018.2016.1250632

Mendelsohn, D. (1994). Learning to listen: A strategy-based approach for the secondlanguage learner. San Diego, CA: Dominie Press.

O’Malley, J. M., \& Chamot, A. U. (1990). Learning strategies in second language acquisition. Cambridge, England: Cambridge University Press.

O’Malley, J. M., Chamot, A. U., \& Küpper, L. (1989). Listening comprehension strategies in second language acquisition. Applied Linguistics, 10, 418-437. https://doi.org/10.1093/applin/10.4.418

Oxford, R., Cho, Y., Leung, S. and Kim, H. (2004). Effect of the presence and difficulty of task on strategy use: An exploratory study. IRAL (International Review of Applied Linguistics in Language Teaching), 42, 1-47. https://doi.org/10.1515/iral.2004.001

Oxford, R. L. (1990). Language learning strategies: What every teacher should know. Boston: Heinle \& Heinle.

Oxford, R. L. (2011). Teaching and researching language learning strategies. Essex, UK: Pearson Longman.

Rahimirad, M., \& Shams, M. R. (2014). The effect of activating metacognitive strategies on the listening performance and metacognitive awareness of EFL students. International Journal of Listening , 28, 162-176. doi:10.1080/ 10904018.2014.902315

Rasekh, Z. E. \& Ranjbary, R. (2003). Metacognitive strategy training for vocabulary learning. Retrieved May 18, 2007 from http://www-writing.berkeley.edu/TESLEJ/ ej26/a5.html

Rees-Miller, J. (1993). A critical appraisal of learner training: theoretical bases and teaching applications. TESOL Quarterly, 27(4), 679-689. https://doi.org/10.2307/3587401

Ridgway, T. (2000). Listening strategies: I beg your pardon? ELT Journal, 54(2), 179185. https://doi.org/10.1093/elt/54.2.179

Rossiter, M. J. (2003). The effects of affective strategy instruction in the ESL classroom. In N. J. Anderson (Ed.), Special issue: Strategy research and training. TESLEJ, 7; (pp. 1-20), 2.

Rost, M. (2011). Teaching and researching listening (2nd ed.). Harlow, England: Pearson Education Limited.

Rubin, J. (1995). An overview to 'A Guide for the teaching of second language listening'. In D. Mendelsohn and J. Rubin (Eds.) A guide for the teaching of second language listening (pp. 7-11). San Diego, CA: Dominie Press.

Sasaki, M. (2004). A multiple-data analysis of the 3.5-year development of EFL student writers. Language Learning, 54(3), 525-582. https://doi.org/10.1111/j.00238333.2004.00264.x 
Scovell, D., Pastellas, V., \& Knobel, M. (2004). 404 essential tests for IELTS general training module. Sydney, Australia: Adams \& Austen Press.

Siegel, J. (2014). Exploring L2 listening instruction: Examinations of practice. ELT Journal, 68 (1), 22-30. https://doi.org/10.1093/elt/cct058

Thompson, I., \& Rubin, J. (1996). Can strategy instruction improve listening comprehension? Foreign Language Annals, 29, 331-342. https://doi.org/10.1111/j.1944-9720.1996.tb01246.x

Tsui, A. B., \& Fullilove, J. (1998). Bottom-up or top-down processing as a discriminator of L2 listening performance. Applied Linguistics, 19, 432-451. https://doi.org/10.1093/applin/19.4.432

Vandergrift, L. (1997). The comprehension strategies of second language (French) listeners: A descriptive study. Foreign Language Annals, 30, 387-409. https://doi.org/10.1111/j.1944-9720.1997.tb02362.x

Vandergrift, L. (2002). "It was nice to see that our predictions were right": developing metacognition in L2 listening comprehension. Canadian Modern Language Review, 58(4), 555-575. https://doi.org/10.3138/cmlr.58.4.555

Vandergrift, L. (2003). Orchestrating strategy use: Toward a model of the skilled second language listener. Language Learning, 53, 463-496. https://doi.org/10.1111/14679922.00232

Vandergrift, L. (2004). Listening to learn or learning to listen? Annual Review of Applied Linguistics, 24, 3-25. https://doi.org/10.1017/S0267190504000017

Vandergrift, L. (2007). Recent developments in second and foreign language listening comprehension research. Language Teaching, 40, 191-210. https://doi.org/10.1017/S0261444807004338

Vandergrift, L., Cross, J. (2015). Replication research in L2 listening comprehension: A conceptual replication of Graham \& Macaro (2008) and an approximate replication of Vandergrift \& Tafaghodtari (2010) and Brett (1997). Language Teaching, 1-10. doi:10.1017/ S026144481500004X

Vandergrift, L., \& Goh, C.C.M. (2012). Teaching and learning second language listening. New York: Routledge. https://doi.org/10.4324/9780203843376

Vandergrift, L. \& M. H. Tafaghodtari (2010). Teaching L2 learners how to listen does make a difference: An empirical study. Language Learning, 60 (2), 470-497. https://doi.org/10.1111/j.1467-9922.2009.00559.x

Yeldham, M., \& Gruba, P. (2014). Toward an instructional approach to developing interactive second language listening. Language Teaching Research, 18, 33-53. https://doi.org/10.1177/1362168813505395 